\title{
AN ECOFEMINIST READING OF MARGE PIERCY'S WOMAN ON THE EDGE OF TIME
}

\section{Gönül BAKAY*}

ABSTRACT: Widely considered to be a landmark of feminist fiction, Woman on the Edge of Time (1976) critically examines many problems of the 20th century (that persist in our age) including, primarily, environmental deterioriation, destruction of animal and plant life as well as the oppression of women. The novel tells the story of a thirtyseven year old Chicano woman named Connie who is unmistakenly a product of her time and class. She has been mistreated by most of the men in her life and forced into a life of destitution. After defending her niece from the latter's pimp/lover, she is institutionalised for the second time and has to endure further humiliation and marginalisation. It is in the mental institution that she is contacted by Luciente who conducts her to a utopian futuristic world which is remarkably different than the one she lives in. In the light of these preliminary observations, the aim of this article is to offer an ecofeminist reading of Woman on the Edge of Time with empasis on the novel's critique of capitalist patriarchy and its advocacy of a more egalitarian society.

Keywords: Ecofeminism, science fiction, utopia, patriarcy, gender, class, oppression, Woman on the Edge of Time, Marge Piercy

\section{MARGE PIERCY'NIN ZAMANIN UCUNDAKI KADIN ROMANININ EKOFEMINIST BİR OKUMASI}

ÖZ: Feminist edebiyatın mihenk taşlarından biri olarak görülen Zamanın Ucundaki Kadın (1976), yirminci yüzyılın (günümüzde de yaşanmaya devam eden) başta çevresel bozulma, hayvan ve bitki yaşamının yok edilmesi ve kadınların gördüğü zulüm olmak üzere pekçok sorununu eleştirel bir bakış açısıyla irdeler. Roman hiç şüphesiz yaşadığı dönemin ve sınıfın bir ürünü olan otuzyedi yaşında meksika kökenli Connie adında bir kadının hikayesini anlatır. Hayatı boyunca birçok erkek tarafından kötü muameleye uğrayan Connie bedbaht bir yaşam sürmeye mahkum olur. Yeğenini onu erkeklere pazarlayan (aynı zamanda sevgilisi) adamdan korumaya çalışırken ikinci kez bir kliniğe yatırılır ve bu süreçte daha da beter aşağılanmaya ve ötekileştirilmeye maruz kahır. Klinikte yatarken onunla iletişime geçen Luciente, Connie'yi kendi dünyasından oldukça farklı geleceğe ait ütopist bir dünyaya götürür. Bu gözlemler ışı̆̆ında bu makalenin amacı, romanın kapitalist ataerkillik ve daha adaletli bir toplum tahayyülüne vurgu yaparak onu ekofeminist bir bakış açısıyla incelemektir.

Prof. Dr., Bahçeşehir University, Department of American Culture and Literature, gonulbakay@gmail.com, ORCID: https://orcid.org/0000-0003-0444-6563

Geliş Tarihi (Received): 17.05.2018

Kabul Tarihi (Accepted): 09.01.2019

Yayın Tarihi / Published: 20.01.2019 


\begin{abstract}
Anahtar Kelimeler: Ekofeminism, bilim kurgu, ütopya, ataerkillik, cinsiyet, sınıf, zulüm, Zamanın Ucundaki Kadın, Marge Piercy
\end{abstract}

\title{
1- Introduction
}

Marge Piercy's celebrated utopian speculative science fiction novel Woman on the Edge of Time (1976) tells the story of a thirtyseven year old Chicano woman named Connie who is unmistakenly a product of her time and class. She has been mistreated by most of the men in her life and forced into a life of destitution. After defending her niece from the latter's pimp/lover, she is institutionalised for the second time and has to endure further humiliation and marginalisation. It is in the mental institution that she is contacted by Luciente who conducts her to a utopian futuristic world which is remarkably different than the one she lives in.

Widely considered to be a landmark of feminist fiction, Woman on the Edge of Time critically examines many problems of the 20th century (that persist in our age) including, primarily, environmental deterioriation, destruction of animal and plant life as well as the oppression of women. Reflecting on the themes and issues of her classic novel forty years after its publication in the Guardian, Piercy remarks: "The point of a novel about the future is not to predict it; I'm not pretending to be Nostradamus. The point of such writing is to influence the present by extrapolating current trends for advancement or detriment" ${ }^{\text {. }}$. For Piercy, political confrontation is not merely a choice but a responsibility. She argues that women should aim to subvert the social order that is based on the patriarchal system. They should also aim to gain more political power in order to change the world and make it a more habitable place. Piercy's arguments intersect with the main tenets of ecofeminism which seeks to dismantle all value hierarchies by highlighting, primarily, the dual subjugation of women and nature. In so doing, ecofeminists target age old patriarchal premises and promote the creation of a more inclusive and egalitarian society. In the light of these preliminary observations, the aim of this article is to offer an ecofeminist reading of Woman on the Edge of Time with empasis on the novel's critique of patriarchal society, value hierarchies and its advocacy of a more egalitarian society.

\section{2- Ecofeminism and The Woman on the Edge of Time}

Ecofeminism combines ecological and feminist perspectives by focusing on not only showing but also redressing the subjugation of women and

\footnotetext{
${ }^{1}$ Marge Piercy, "Woman on the Edge of Time, 40 years on: 'Hope is the engine for imagining utopia", The Guardian, 29.11.2016.
} 
nature. Piercy's novel is very much steeped in ecofeminist thinking aptly summarized by Greta Gaard in the following words:

"Ecofeminists have described a number of connections between the oppressions of women and nature that are significant to why feminist issues can be addressed in terms of environmental concerns. For example, the way in which women and nature have been conceptualized historically in the Western intellectual tradition has resulted in devaluing whatever is associated with women, emotion, animals, nature, and and the body while simultaneously elevating simultaneously elevating alue those things assocated with men, reason, humans, culture and the mind. One task of ecofeminists has been to expose these dualisms and the ways in which feminizing nature and naturalizing or animalizing women has served as justification for the domination of women, animals and the earth"2

Woman on the Edge of Time successfully speaks to all of these concerns by focusing on how the intolerable treatment of the downtrodden, especially women and the poor, goes hand in hand with the violation of nature. The novel also offers a utopian alternative to the dystopian reality it depicts by showing through the example of Mattapoisett that a more pluralist and fair social organisation is possible. The story of the narrative takes place in two settings: the New York of 1976 and Mattapoisett in 2137. On the one hand, the book analyzes the daily events of 1976, and on the other hand, it deals with scientific discoveries that affect the present and probably the future. Like ecofeminists, Piercy questions the whole system of binary oppositions that inform Western thought throughout the novel. Simultaneously, the author also aims to present a vision of an alternative world where there would be no oppression of women and nature. In this sense, although this is mainly a book about womanhood and how women suffer under the yoke of patriarchy, it also offers an alternative (utopian) perspective that stands for a much more ideal society.

The protagonist of the novel is Connie whose life as a poor Chicana woman is depicted through her relationships with her two husbands and lovers. In the words of Yiğit Sümbül, Connie Ramos "is the ultimate example of the contemporary working class woman, victim of multiple abuses like racism and domestic violence, suffering from financial hardships, problematic marriages and being an only parent, and struggling against a system of ideologies that vies her as naturally irrational. ${ }^{3} \mathrm{Her}$

${ }^{2}$ Greta Gaard, Ecofeminism: Women, Animals, Nature. Philadelphia: Temple University Press, 1993, p. 5.

${ }^{3}$ Yiğit Sümbül, "Marge Piercy's Conception of a Feminist Utopia in Woman on the Edge of Time”, Dil ve Edebiyat Dergisi, Vol. 2, Issue 10, 2014, p. 174. 
first husband is killed by the police in a street brawl. Her second husband abuses her physically which leads her to run away and her lover dies in the prison where he is used as a subject in an experiment. Connie gets into a fight with her niece Dolly's pimp Geraldo because he tries to convince Dolly to have an abortion. When Connie hurts Geraldo, the latter commits her into an asylum. Connie's story starts with her second institutionalization, but her past life is recounted through the use of flashbacks. She is first intitutionalized because of her violent behavior towards her own daughter, Angelina.

Throughout her formative years, Connie constantly keeps looking for her mother's love that her mother fails to give her. Connie is raised in a patriarchal society where sons are considered more valuable than daughters. Moreover, Connie's mother cannot give her daughter the necessary physical, emotional and financial support to enable her to become independent and self sufficient. Connie tells her mother that she doesn't want to be like other women. At fifteen, she stands before her mother and observes: "I won't grow up like you Mama! To suffer and serve. Never to live my own life! I won't."4 She also adds that she is going to go to college and live a good life, a life of her own choosing. When her mother reminds her that even Luis, her brother, cannot go to college, Connie responds:

I can! I am going to get a scholarship. I am not going to lie down and be buried in the rut of family, family, family! I am so sick of that word, Mama! Nothing in life but having babies, and cooking and keeping the house. Mamacita, believe me - oigame, Mama - I love you! But I am going to travel. I am going to be someone. ${ }^{5}$

As this passionate outburst suggests, Connie is far from being content with the destiny cut out for her and is rather eager to become the best possible version of herself. As a result, she defiantly rejects the norms of patriarchal society which limits her chances in life. Unfortunately, Connie does not end up living the life she is determined to live. She goes to college for two years but has to drop out abruptly. Because she cannot afford a typewriter, she tries to earn money by typing the papers of a white student, yet she becomes pregnant by him and then is forced to leave college. She later meets a black saxophone-player and a pickpocket who dies after he accepts taking part as a guinea pig in an experiment in the prison. Connie is devastated by these events and takes to drinking and drugs. Deeply disturbed and depressed, she hits her own child, breaks her wrist and is then sent to

\footnotetext{
${ }^{4}$ Marge Piercy, Woman on the Edge of Time. London: the Woman Press, 1979, p. 46.
}

${ }^{5}$ Ibid., p. 46. 
prison. Her daughter, on the other hand, is sent to a foster home and then to an asylum. When Connie hits her niece's pimp Geraldo with a bottle, the latter puts her in a mental hospital after he gets a doctor to diagnose her as with schizophrenia. As Judith Kegan Gardner observes: "The pimp and the mad doctor thus stand as the two examplary villains of this society. Both profit from turning the private realms of sexuality and of mental fantasy into institutions of exploitation." 6

This unfortunate event marks the beginning of Connie's life as a mental patient locked up against her will in a mental institution. In this context, her story also allows the reader to observe the terrible conditions of the hospitals where sick people are "treated". Even the relatives of patients, such as Connie's niece Dolly, collaborate with the doctors who aim to destroy the patients. Throughout her life, Connie had been abused by men. Her pregnancy was a result of rape and she becomes barren as a result of the experiments performed on her in the mental hospital. Drawing a clear connection between the horrible treatment Connie was subjected to and her subsequent mental collapse, Piercy wants the reader to think deeply about Connie's so-called madness. In fact, she goes as far as to suggest that Connie's madness is brought about by the suffering inflicted on her by patriarchal society. I would also add that Connie is considered mad by the majority because she does not display the conventional behaviours expected of women.

Piercy also draws attention to the fact that in our world, people have no respect for human life. Claude, Connie's lover, is put in the prison for picpocketing but in order to get some money, and hoping that maybe they would shorten his stay in the prison, he agrees to participate in a scientific experiment: "They had injected him with hepatites and the disease had run its course and he had died. Her probation officer, Briggs would not let her go to the funeral."

One morning Connie wakes up in the hospital ward with a nice Indio called Luciente, who - holding her hand - says "come". In the words of Elham Afnan: "Luciente's role is analogous to that of the author, both of them not only present the distinguishing features of a new society, but they also try to stimulate in their auditor/reader the activism that will bring that

\footnotetext{
${ }^{6}$ Judith Kegan Gardner, Provoking Agents: Gender and Agency in Theory and Practice. Illinois: Illinois Press, 1995, p. 75.

${ }^{7}$ Ibid., p. 27.
} 
society into being". ${ }^{8}$ Following Luciente, Connie then enters a futuristic world where the conditions are very different compared to her own habitual reality. Mattapoisett, the place she is transported into, is the community of the future. It is roughly the size of a village and "the community lives in rural conditions where cows graze and pure vegetables are grown. It reminds Connie of the Mexican village." In making agricultural activity central to the utopians' culture and society, Piercy displays an ecofeminist sensibility. As Soraya Copley suggests in "Rereading Marge Piercy and Margaret Atwood: Eco-feminist Perspectives on Nature and Technology" (2013): "Fundamental to the Utopians' ability to implement humanitarian and environmentally friendly practices is the anti-hierarchical character of their group relations which emphasize debate, cooperation and consensus decision-making." 10 Thus, their society poses a stark contrast to the world depicted in the novel where human bodies along with nature are pillaged, exploited and then discarded. In true ecofeminist fashion, Piercy also portrays this "real" world as a place where ruthless male dominance in the society produces all kinds of social ills and corruption.

Ecofeminists call for the forging of life-sustaining connections and relationships across differences such as class, gender as well as species. Mattapoisett is a place where such connections have become living reality: "This utopian community manages successfully to integrate advanced technology, social planning, individual liberty, and a close connection to nature, based on Third World cultures and the culture of the Wamponaug Indians. All citizens of Mattapoisett are valued and loved, and all are treated equally regardless of race, gender, or other differences. In short, this society accepts and even welcomes precisely the differences that have marginalized Ramos in her own." 11

As ecofeminists point out, there is a very close relationship between the maltreatment of women and nature (including non-human animals). In a world where people have no respect for human life, they have no respect for animal life as well. In stark contrast, in Mattapoisett, animals are valued and respected. Their attitude towards non-human animals is illustrated in the

\footnotetext{
${ }^{8}$ Elham Afnan "Chaos and Utopia: Social Transformation in Woman on the Edge of Time" Extrapolation. 37.4, Winter 1996, p. 330.

${ }^{9}$ Miriam Rosenthal, "Woman on the Edge of Time: Observations" http://www.futures.hawaii.edu/publications/half-fried-ideas/J2/rosenthal.pdf, p. 2.

${ }^{10}$ Soraya Copley, "Rereading Marge Piercy and Margaret Atwood: Ecofeminist Perspectives on Nature and Technology" Critical Survey, Vol. 25, No. 2, 2013, p. 44.

${ }^{11}$ M. Keith Booker, "Woman on the Edge of a Genre: The Feminist Dystopias of Marge Piercy” Science Fiction Studies, Vol. 21, No. 3, November 1994, p. 340.
} 
following words by Luciente who talks about Tilia (the cat) in terms of a sensitive human being: "For instance, Tilia and I talk sign language based on cat signs but modified - because many things must be said between cat and human different from what is said between cat to cat." ${ }^{12}$ Connie observes: "Either you are putting me on or you are crazier than I am." Luciente continues very seriously: "I'll teach you how to meet a cat. Cats are formal about introductions. I got flack last time. Look, Tilia can express feeling puffed. If Tilia takes a flying leap onto my chest from at first dawn from the top of the wardrobe, I get a clean notion that the cat is dissatisfied with my conduct." 13

In her essay "Animal Rights and Feminist Theory" Josephine Donovan examines the rights of animals in our carnivorous society: "from cultural feminist point of view the position developed by utilitarian animal rights theorists is more tenable in this regard because it dispenses with the higher intelligence criterion, insisting instead on the capacity to feel-or the capacity to suffer-as the criterion by which to determine those who are entitled to be treated as ends." ${ }^{14}$ Like ecofeminits, the inhabitants of Mattapoisett show great respect for all sentient beings and believe in the value of ecological and plant intelligence. In the novel Luciente talks about how their ideas, feelings about animals changed their eating habits. He observes: "It's changed our diet. So has the decision to feed everyone well. For each region we try to be ownfed and untill the former colonies are equal in production, mammal meat is inefficient use of grains." 15

\section{3- Mattapoisett as an ecofeminist Utopia}

This futuristic world allows Piercy to criticize the major comtemporary problems from an ecofeminist lens. The pollution of water resources is of paramount importance since it seriously affects the plant and the vegetable life. "Can ecofeminism withstand corporate globalization?" Heather Eaton asks. She continues: "Meanwhile the disintegration of the art accelerates. Water is becoming an international market - commodity, not a basic need or right." 16 The destruction or pollution of the earth's natural sources is one of the major issues the novel adresses. Luciente says to Connie: "I don't mean to hurt your feelings, Connie. I'm sure many of the tales we hear are gross exaggerations. Such as the idea that you - you prulal - put your shit into the

${ }^{12}$ Ibid., p. 98.

${ }^{13}$ Ibid., p. 98.

${ }^{14}$ Josephine Donovan, “Animal Rights and Feminist Theory,” Signs, Vol. 15, No. 2, Winter, 1990, p. 171.

${ }^{15}$ Ibid., p. 100.

${ }^{16}$ Ibid., p. 27. 
drinking water." ${ }^{17}$ Connie answers that she never heard such nonsense. Luciente wants to know where the food waste goes. Connie answers that they put it in cans and the city comes and takes it away. When asked what the city does with it, she answers "they burn it" Luciente is shocked and comments: "But to burn your compost! To pour your shit into waters others downstream must drink! That fish must live in! Into rivers whose estuaries and marshes are links in the whole offshore food chain! Wait till I tell Bee and Jackrabbit." ${ }^{18}$ Luciente also tells Connie that they send their garbage to the earth. He observes: "we compost everything compostable. We reuse everything else." 19

Another important ecological issue the novel brings to attention is the preservation of land which also directly affects weather conditions. Luciente observes: "About weather, when it gets disastrous, sometimes we adjust a little. But every region must agree. When a region is plagued by drought, grasp, we usually prefer to deliver food, than to approve a weather shift. Because of the danger. We are cautious about gross experiments. 'In biosystems, all factors are not knowable.' First rule we learn when we are studying living beings in relation..." ${ }^{20}$ So the inhabitants of Mattapoisett have not only developed technologies to manipulate weather conditions but they also do it in a democratic fashion, always watching out for the maximum benefit for all parties involved. Their policies and actions illustrate that they prioritise commitments to one another as well as to the biosystem since they believe we are all part of an interconnected whole.

In this utopian world, gender roles are also significantly reformed and the society thus appears to be much more egalitarian: both mothers and fathers share housework and childcare. Nobody is ostracised due to their gender and/or sexual preferences. This reflects the ecofeminist concern for cultivating fair and mutually beneficial relations amongst all humans, animals and nature. In the words of Billie Maciunas: "Piercy's valuation of interpersonal relations (to the point of an absolute intolerance for violence) reflects the feminist standpoint epistemology in which relational forms of knowing are regarded as morally preferable to the objectification of individuals and groups."21

\footnotetext{
${ }^{17}$ Ibid., p. 54.

${ }^{18}$ Ibid., p. 55

${ }^{19}$ Ibid., p. 55.

${ }^{20}$ Ibid., p. 97.

21 Billie Maciunas, "Feminist Epistemology in Piercy's Woman on the Edge of Time" Women's Studies, Vol. 20, 1992: p. 254.
} 
The contrast between the real dystopian world and the utopian Mattapoisett is also apparent in the treatment of madness in the latter. Strikingly, this utopian society also entertains a very different perception of madness which they consider to be a rather normal aspect of life. Luciente (the androgenous figure from the future) says:

“...our mad houses are places where people retreat when they want to go into themselves, to collapse, carry on, see visions, hear voices of prophecy, bang on the walls, relive infancy, getting in touch with the buried self and the inner mind. We all lose part of ourselves. We all make choices that go bad... How can another person decide that it is time for me to disintegrate, to reintagrate myself?"22

So "madhouses" in Mattapoisett are places where people meditate on their being and the meaning of life. Thus, the people who enter these places are not stigmatized as outcasts and instead use this "opportunity" to discover hitherto hidden aspects of themselves. Mattapoisett appears to be a utopian society in other respects as well: Agriculture is people's main occupation. Children are perceived as belonging to the community. Births are controlled. A child is only allowed to be born when someone dies... All in all, the novel raises several questions in the readers' minds regarding doctor-patient relationships, the conditions of asylums, the dangerous experiments the doctors perform on patients, the meaning of progress and whether there will be a return to the past to find peace and harmony.

Connie has always been oppressed by men: one of her husbands attacks her physicaly, her niece's pimp puts her in a mental hospital with the help of a doctor and she loses her fertility because of the experiments performed on her. In contrast to the cruel behavour of the doctors and nurses in the real world, Mattapoisett is charactarized by harmonious co-existence. Women are allowed enjoy fully the freedoms that men have. Luciente, whose name means illuminating, enlightining, resembles a man; and yet "he lacked the macho presence of men in her own family, nor did he have Claud's massive strength, or Eddie's edgy combativeness." ${ }^{23}$ Luciente is sure of himself and independent. It is he who becomes Connie's guide in this futuristic world. Luciente also seems to be profoundly sensitive and perceptive. He says to Connie: "you don't seem mad to me." 24 Although the inmates of Connie's hospital, Alice, Skip and Sybil are labeled as "monsters" by the medical staff they seem to be more reasonable and sane.

${ }^{22}$ Ibid., p. 66

${ }^{23}$ Ibid., p. 64.

${ }^{24}$ Ibid., p. 65. 
Throughout the novel, Piercy also suggests that the loss of mental balance may have some seemingly positive consequences. By returning to herself in a secluded environment and engaging in serious soul-searching, the individual can discover her hidden talents and personality traits. In the Connie's "real" world, however, mental institutions are employed to annihilate the "identity" of the individual if it does not conform to societal standards. Because they can not come into terms with their son's homosexuality, Skip's family send him to the mental hospital, hoping they can "fix" him there. But Skip does not change and eventually commits suicide under such increadible mental strain. However, Jackrabbit (his counterpart in the futuristic world) is accepted and loved for who he is. In this sense, Piercy draws attention to the fact that in this alternative world, difference is not suppressed or punished but instead is welcome.

Ecofeminists draw attention to the parallel between the bad treatment and abuse of women and our earth by phallocentric capitalism. Considering Woman on the Edge of Time to be an ecofeminist work, Deirdre O'Byrne draws attention to the fact that Piercy is inspired by several customs, modes of behaviour and agricultural methods from the past in this novel. For instance, people try to grow organic food by using certain methods employed in the past. Young people are sent to the forest alone to prove that they have reached the age of puberty. ${ }^{25}$ In this alternative futuristic world, it is important for people to have their own personal space. Luciente cannot comprehend how people can live cramped together.

Childcare is one of the major issues ecofeminists draw attention to. Because of the necessity of work for the mothers of babies, most are forced to leave their babies at care centers where the conditions are far from ideal. Luciente observes: "Birth! Birth! Birth! That's all you can dream about! Our dignity comes from work. Everyone raises the kids, haven't you noticed? Romance, sex, birth, children - that's what you fasten on. Yet that isn't women's business anymore. It's everybody's." ${ }^{26}$ Janis Birkeland observes that women are at the mercy of power mechanisms. She observes:

"If women had physical security (food, shelter, health care) and control over their own bodies, and were not subject to androcentric cultures, the population and child mortality would both decrease. Few would have large families- if only because pregnancy and childcare are too much work... Patriarchal societies that equate personal worth with success, success with

\footnotetext{
${ }^{25}$ Deirdre O'Byrne, Marge Piercy's Non-Utopia in Women on Edge of Time. Leicestershire: Five Leaves Publications, 2012, p. 4.

${ }^{26}$ Ibid., p. 251.
} 
masculinity, place pressure on men to produce many offspring. Moreover, governments use women to provide children for military strength and markets for growth- based development.. Women trusts and colonies are objectified as natural sources" 27

Ecofeminists argue that environmental destruction and social injustice (racism, poverty sexism) have a common cause- a particular kind of hierarchical thinking. They believe that the rich abuse and oppress the poor, similar to men oppressing women. When Connie realizes that she cannot reach Luciente, she thrusts herself to the future world but she lands in New York. There she meets a woman named Gildina who is a prostitute. She tells Connie that her mother died at forty-three. When Connie comments that she was so young, Gildina observes: "How long do you suppose to live? Only the richies live longer, it's in their genes. Like they say, it's all in the genes. Connie asks: 'How long do the richies live?' - "Oh, maybe two hundred years. Depends on what they can afford - you know, the medicos, the organs. I've never actually met one, of course, I never been off the surface." 28

A fundamental aspect of living as an authentic person is the liberty to enjoy sexual freedom and make one's own sexual choices. So in Mattapoisett, there is no social pressure on sexual or gender preferences. People can have sexual relations with people of their own gender or with those of the opposite sex. The sexual choices people make cause no problems or complications. Embryos are raised in places resembling an aquarium and mothers do not carry their babies in their wombs. Childcare is shared by both sexes and hence is not solely the work the mother so that mothers can continue doing their work. At first, Connie hates these factorylike places where children are produced and raised but Luciente explains to her that this arrangement is essential for the freedom of women. Although Connie does not completely approve of this system, she nevertheless thinks that her daughter could have been happier had she been raised in such an environment.

The critic Richard McCarthy asks whether the futuristic world Connie visits is real or the product of a mad woman's imagination. In his words: "unfortunately I believe The Mattapoisett utopia that Connie has created is the product and fantasy created by the confining conditions of the mental hospital and explains her behaviour and psychosis." 29 McCarthy further

${ }^{27}$ Qtd in Greta Gaard (edt.), Ecofeminism: Women, Animals and Nature. Philadelphia: Temple University Press,1993, p. 34.

${ }^{28}$ Ibid., p. 291.

${ }^{29}$ Richard McCarthy, "Modern Classic Book Review: Woman on the Edge of Time by Marge Piercy," The Ooh Tray, February 9 2011, p. 3. 
suggests that the utopia created by Connie is the product of her of her own experiences. In this community, there is no rape, assault, theft or murder. These are all events in her life that have given pain to Connie. Connie sees Luciente as her own double. Luciente is the successful scientist Connie always wanted to become. Moreover, the utopian Mattapoisett seems to be a place where many of her desires and aspirations have been realized; a place where her daughter could live in a safe environment, where she could reunite with her lover Claude and also enjoy some peace and quiet. Although Connie is presented as a mentally unstable woman and the futuristic world she created may be considered her fantasy, the social arrangements regulating reproduction and birth are remarkably rational and reasonable.

Piercy's novel takes a strong view regarding psychiatry as an institution. In doing that, the novel also questions various practices and research in this field that may sometimes have dangerous consequences for the patients. It is important to remember that Connie is particularly vulnerable as a poor hispanic woman with no one to protect her. She is thus in a more disadvantegous position when compared with white women of a higher social standing. It is thus the combined forces of gender, racial and class discrimination that lead to her victimization and suffering.

Towards the end of the book, Connie is selected for a scientific experiment. Doctors intend to put an implant in her brain which they believe will control Connie's nervous outbursts. Connie tries to resist this experiment and tries to escape from the asylum but fails to do so. Because she cannot escape the asylum, she poisons the doctors who intend to operate on her. The book does not offer a neat satisfying ending - as in life there are very few satisfying endings to stories. Connie is poor, hispanic, and lives on the periphery of society. Was Connie mad? Or were the people in her environment insane? The novel leaves this as an open ended question.

\section{4- Conclusion}

All in all, Woman on the Edge of Time is a classic work of ecofeminist fiction in its exploration of issues central to ecofeminism. In the words of Sam Mickey, the point of ecofeminism not to focus on nature and women to the exclusion of everything else: "The point is rather to focus on the interconnections and Networks of coexistence, which include the entangled categories of race, class, age, ability, religion, nationality, ethnicity, and many others, along with species, gender, and sexuality. In other words, the point of ecofeminism is fundamentally intersectional, attending to the multitudinous ways in which the various aspects of coexistence 
interconnect." ${ }^{30}$ Likewise, the novel as a whole shows how one needs to consider all forns of injustice and discrimation as part of the same whole in order to create a more egalitarian and pluralistic society. Near the end of the book, Luciente - voicing Piercy's wish for a utopia - observes that maybe the future may be better than today. He observes:

"Someday, the gross repair will be done. The oceans will be balanced, the rivers flow clean, the wetlands and the forests flourish. There'll be no more enemies. No Them and US. We can quarrel joyously with each other about important matters of idea and art. The vestiges of old ways will fade. I can't know that time - any more than you can ultimately know us. We can only know what we can truly imagine. Finally what we see comes from ourselves" 31

Here, Luciente offers a vision of what could be if we value all forms of intelligence including those of the ecological, human and non-human animals. Works of speculative science fiction play a very important role in the cultivation of such an awareness since: "Developing such a planetary conscience could only be possible with a new imaginary to foster and support it [...] In their capacity to offer vivid articulations of alternative futures, they can be utilized as powerful tools to engage the readers' imagination since they draw on past and current issues in order to present a wide range of future possibilities". ${ }^{32}$

To conclude, one can observe that, by shifting the narrative back and forth in time and connecting the present, past and the future, Piercy aims to show the interrelatedness of these time periods. In doing that, her main aim is to draw attention to the parallels between the oppression and subjugation of women and nature. In the words of Jeffrey Bile: "It is one thing to notice that the oppressions of women and nature overlap but quite another to contend that they are connected. Despite many differences, ecofeminist scholars normally insist that overlapping repression of of "the feminine" and of 'the ecological' are more than coincidental." 33 Feeling trapped in this hostile environment, the main character suffers from alienation and mental disorder. She is then labelled as "mad" by the very same forces that have

\footnotetext{
${ }^{30}$ Douglas A. Vakoch and Sam Mickey (eds.), Literature and Ecofeminism: Intersectional and International Voices, Oxon: Routledge, 2018, p. xvii.

${ }^{31}$ Ibid., p. 328.

${ }^{32}$ Hatice Övgü Tüzün, "Welcome to the Desert of the Anthropocene: Dystopian Cityscapes in (Post)Apocalyptic Science Fiction” American, British and Canadian Studies 30.1, 2018, p. 189-190.

${ }^{33}$ Qtd in Douglas Vakoch, (edt), Ecofeminism and Rhetoric. Oxford: Berghahn Books, 2011, p. 6.
} 
driven her "insane". In this sense, her so-called descent into "madness" can be perceived as a defense mechanism, as a manifestaiton of her desire to find a space within which she can find safety and fulfillment. Even though this fantasy world might be a work of her creative imagination, it is more real to her than the real world which has offered her nothing but pain and suffering.

Ultimately, this ecofeminist novel proposes that we should subvert the underlying patriarchal norms and value hierarchical thinking as well as the structural relations of our culture in order to promote gender equality, nonviolence and non-hierarchical forms of organisation. According to Kim Trainor:

"As readers we are drawn imaginatively into both worlds but, at the same time, allowed a certain critical distance in order to analyse what is wrong with the way Connie is being treated, and what is right. Our imaginative empathy is called upon: the sense of being drugged and dragged back into the servitude Connie experiences within the mental hospital is almost palpable, contrasted with the lightness we experience when the narrative to the future world of Mattapoisett. In this juxtaposition of dystopian and utopian worlds the reader experiences with Connie Ramos first a diminishing and then a flourishing of her human capabilities" ${ }^{\prime 34}$

As Marge Piercy successfully shows in Woman on the Edge of Time, when we take on an ecofeminist perspective regarding relationality, we can take a more pro-active stance regarding several pressing issues we face as a collective on a rapidly decaying planet such as pollution, degradation of natural resources, species extinction as well as various forms of injustice and discrimination. In the words of Wangari Maathai and Vandana Shiva: "Things will not just happen. Women must make things happen. The capacity to weep and and then do something is worth everything. We want to remember that emotions are things we value. Ceating change globally - this is not something you can do in your spare time. We all have to live it." ${ }^{, 35}$

\section{REFERENCES}

Afnan, Elham. "Chaos and Utopia: Social Transformation in Woman on the Edge of Time”, Extrapolation, 37.4, Winter 1996, pp. 330-340.

\footnotetext{
${ }^{34}$ Kim Trainor "What Her Soul Could Imagine: Envisioning Human Flourishing in Marge Piercy's Woman on the Edge of Time" Contemporary Justice Review Vol. 8, No. 1, March 2005, p. 38

35 Qtd in Greta Gaard, Ecofeminism: Women, Animals, Nature. Philadelphia: Temple University Press, 1993, p. 3.
} 
Booker, M. Keith "Woman on the Edge of a Genre: The Feminist Dystopias of Marge Piercy", Science Fiction Studies, Vol. 21, No. 3, November 1994, pp. 337-350.

Copley, Soraya, "Rereading Marge Piercy and Margaret Atwood: Ecofeminist Perspectives on Nature and Technology" Critical Survey, Vol. 25, No. 2, 2013, pp. 40-56.

Donovan, Josephine. "Animal Rights and Feminist Theory," Signs, Vol. 15, No. 2 , Winter 1990, pp. 350-375.

Eaton, Heather and Lois Ann Lorentzen (edts). Ecofeminism and Globalization: Exploring Culture, Context and Religion, Maryland: Rowman and Littlefield Publishers Inc., 2003

Gaard, Greta, (edt), Ecofeminism: Women, Animals, Nature, Philedelphia, Temple University Press, 1993.

Gardner, Judith Kegan, Provoking Agents: Gender and Agency in Theory and Practice, Illinois: İllinois Press, 1995.

Maciunas, Billie "Feminist Epistemology in Piercy's Woman on the Edge of Time" Women's Studies, Vol. 20, 1992, pp. 249-258.

McCarthy, Richard. "Modern Classic Book Review: Woman on the Edge of Time by Marge Piercy", The Ooh Tray, February 92011.

Michael, Cornier Magali, Feminism and the Postmodern Impulse, New York: State University of New York Press, 1996.

O'Byrne, Deirdre, Marge Piercy's Non -Utopia in Women on Edge of Time Leicestershire: Five Leaves Publications, 2012.

Piercy, Marge. Women on The Edge of Time. London: The Women Press, 1979.

Rosenthal, Miriam. "Woman on the Edge of Time Observations", http://www.futures.hawaii.edu/publications/half-fried-ideas/J2/rosenthal.pdf

Sümbül, Yiğit. "Marge Piercy's Conception of a Feminist Utopia in Woman on the Edge of Time" Dil ve Edebiyat Dergisi, Vol. 2, Issue 10, 2014, pp. 174-183.

Trainor, Kim. "What Her Soul Could Imagine: Envisioning Human Flourishing in Marge Piercy's Woman on the Edge of Time", Contemporary Justice Review Vol8, No.1, March 2005, pp. 25-38.

Tüzün, Hatice Övgü. "Welcome to the Desert of the Anthropocene: Dystopian Cityscapes in (Post) Apocalyptic Science Fiction", American, British and Canadian Studies, 30.1, 2018, pp. 171-192.

Vakoch, Douglas (edt). Ecofeminism and Rhetoric. Oxford: Berghahn Books, 2011.

Vakoch, Douglas and Sam Mickey (eds.), Literature and Ecofeminism: Intersectional and International Voices, Oxon: Routledge, 2018. 